\title{
African culture and managerial behaviour: Clarifying the connections
}

\author{
P. Mufune* \\ University of Namibia, Private Bag 13301, \\ 340 Mandume Ndemufayo Avenue, Pioneerspark, \\ Windhoek, Namibia \\ pmufune@unam.na
}

Received June 2003

\begin{abstract}
There is an increasing recognition that Management is a critical factor in the running of African organizations and in pulling African countries out of their economic crisis. Although efforts have been made to provide management and administrative training, the role of culture in management remains poorly understood. This paper evaluates studies that look at the role played by African culture in managerial behaviour. It examines how values and approaches derived from African culture may or may not be affecting managers and the functioning of organizations. It examines how African managers diverge from managers in other countries. It concludes by emphasizing that there are many shortcomings in research on the African culture-managerial behavior dynamic. It points to various suggestions that may help clarify the inconclusive results in this area of research.
\end{abstract}

*To whom all correspondence should be addressed.

\section{Introduction}

Several factors have converged to expedite efforts aimed at understanding the nature of management in Africa. First is the recognition that management is a critical factor in the running of organizations. Two decades ago the World Bank (1981) detailed how inadequacies in project analysis, project evaluation, policy formulation and implementation stifled the efficiency and effectiveness of African public (and to some extent private) organizations. Even African governments have from time to time examined the organizational and institutional infrastructure charged with undertaking development activities. At the national level training institutes have been established ostensibly for the purpose of providing training into routine organizational demands and improving every day management. Almost all universities offer courses on management. Many countries established training institutes to improve public administration. Examples include the National Institute of Public Administration (NIPA) in Zambia, Tanzania's Institute of Development Management, The Botswana Institute of Administration and Commerce (BIAC), and the Zimbabwe Institute of Public Administration (ZIPA). Many of these were created with the help of the United Nations Development Programme (UNDP) and the International Labour Organization (ILO) (Kiggundu, 1993). The creation of regional training institutions such as Institute of Development Management (IDM) (Botswana), Eastern and Southern African Management Institute (ESAMI) (Tanzania), Pan African Institute for Development (PAID) (Cameroon), and the Centre for Administrative Training and Research for Development (CAFRAD) (Morocco) have been meant to improve managerial effectiveness. 'They have been established primarily to meet the needs of top level, senior and middle level administrators and managers whose duties and responsibilities have both a national and a regional orientation such as managers of international transport systems, international trade systems and international development projects' (Kiggundu, 1993: 175).

Secondly, many economies in Africa are ailing. They are debt ridden, have foreign exchange shortages and are recording negative growth rates. In the context of searching for economic growth the situation of managers has received attention. 'Whether or not Africa will pull out of its present doldrums may well depend on the quality of its organization and management practices ten to fifteen years from now and beyond' (Kiggundu, 1988: 239). In developing countries where low productivity is an endemic problem, management development has come to be accepted as a powerful management intervention instrument to greater competitiveness (Grzeda \& Assogbavi, 1999). As Mathews (2000:13) has also argued: 'Like their counterparts the world over managers in developing nations are looking for ways to improve efficiency and effectiveness in the work place. In addition, however, these managers have to cope with unique external challenges found within the developing nations. In fact, so different and unique are the challenges of the environments found in developing nations, some have suggested Western management models should be modified to fit them'.

Lastly and more importantly, there is now an extensive reception to the idea that "national and organizational cultures have a major impact on the structure and functioning of organizations as well as their performance 
and problems' (Blunt \& Jones, 1992:189). Managerial behaviour, views and attitudes conform to a given country's cultural heritage rather than to its geographical location or regional economic affiliation (Kanter, 1991). Organizations differ but even if they could be equalized, the informal ways of using organizations differ. 'Informal realities are quite resistant to change' (Hofstede, 1995:141). Culture is particular important to management.

\begin{abstract}
'Management is universally about organization, institutional analysis, motivation, establishing incentives and implementing decisions. And no, not all aspects of these processes, when they are desegregated, function in exactly the same manner in different cultural contexts. The existence of techniques and concepts does not deny the salience of local cultural variation. All languages have verbs, a 'universal' characteristic, but verbs vary in each language. Although all management as a science has some basic unit of analysis, improving managerial and organizational performance requires removing the precise obstacles impeding performance; and these are culturally imbedded' (Bryant, 1994:452).
\end{abstract}

What is the nature of management in organizations that operate in Africa? To what extent do managers and the organizations they run require cultural congruence to operate effectively in the African social cultural environment? What are the consequences for organizations in Africa that fail to adapt to strongly held local norms, values, beliefs and practices? These questions are important for they might help explain why African organizations may not have performed very well for a long time. They may also help us to identify cultural sources of resistance to management practices that affect organizational performance negatively. To manage effectively in organizations that have been imported from Europe, there is need to recognize the differences these organizations represent to African culture and learn to use those differences to raise organizational performance and efficiency. Ignoring the differences will cause problems for African organizations that must compete at a global level. This article is largely conceptual in nature. It examines research material that relates African culture to managerial behaviour and demonstrates its inconclusiveness. It suggests some angles that might help resolve the impulse on this important topic.

\section{Dismissing misconceptions}

Among political scientists perceptions of culture and management in Africa have been distorted by several misconceptions. The first is that both management inefficiencies and ethnic (cultural) differences are hopelessly difficult problems in African countries. In reality, although Africa has many ethnic groups, these manage to live together and have lived together for a very long time. In only a few countries (Rwanda and Burundi being prime examples) has there been all out war based on ethnicity. Others, especially organizational researchers and theorists, commit the opposite fallacy of conflating all African cultures into one. African culture is often construed too narrowly in the mind of Africans and outsiders alike. The common conception is that there is but one African culture that is responsible for the fact that the continent is the most poverty stricken and underdeveloped in the world. A broader and more accurate view of African culture is that there are many African cultures. These are as different as any group of cultures can be. While some emphasize collectivist orientations, others emphasize individualist ones. While some cultures are very egalitarian, others are very hierarchical; while others promote feminine behaviours, others emphasize masculinity etc. 'To think of a monolithic African culture is inaccurate' (Grzeda \& Assogbavi, 1999:416). Another misconception is that managerial inefficiencies are endemic to African cultures. Although Africa lags behind on most development indices some economies are growing rapidly, and some countries have managed their economies quite efficiently. For instance, few people know that Botswana, a country in southern Africa, from the 1970s had one of the longest boom economies in the world. From 1966 to 1996, Botswana's economic growth exceeded that of any other country in the world. In this period, the gross domestic product (GDP) trebled. Furthermore, management inefficiencies and related problems can be ameliorated by investments in education, public health and improvements in the empowerment of female managers, among other policy measures. And African countries have been trying to improve on these.

From this perspective, there is need to see that many management issues are not only linked to culture issues, they may also be cultural issues. When management and culture issues are seen too narrowly, ethnocentric explanations will be advanced and there will be a chance to overlook the problems emphasized above and the organizational employees and countries that suffer from them. When, on the other hand, these issues are viewed broadly, a way is paved for solving some of the more serious problems (Catley-Carlson and Outlaw, 1998) of managerial performance.

\section{Scholarly debates and writings on the links between African culture and management}

There are two different positions on the link between African culture and managerial behaviour. The first is that African culture affects managerial behaviour in such a way that it diverges from managerial behaviour elsewhere. The opposite view holds that African managerial behaviour is essentially converging with management behaviour elsewhere. Before going into the details of these debates it is essential that some of important terms that characterize the contours of this debate are defined.

Managers are here defined as individuals exercising responsibility for the coordination and control of work organizations. They are people who are assigned supervisory duties over the work and work conduct of others. They may belong to senior, middle and lower strata making for wide social economic differences between them. As a group they are professional and technical men and women who have achieved tangible success by making careers out of organization hierarchies. Not only do they maintain and run organizations, they also exercise power. All managers develop certain orientations that help them 
operate in organizations. Work Orientations are here defined as behavioral dispositions individuals have towards relationships bringing them into contact with others at work. They are expressed as a set of paired alternatives on a continuum. They include (but are not limited to) the following: Authoritarianism Vs Participativeness referring to the disposition which allows subordinates at work to contribute to decision making as against shutting them out of the decision making process in the belief that they are best suited to carry out already made decisions. Rulemindedness $V s$ Flexibility refers to the disposition on the part of the individual manager whereby rules are followed to the letter regardless of the situation (i.e. rules become ends in themselves) as against allowing subordinates to interpret rules according to contingencies. Favoritism $V s$ Universalism refers to the disposition allowing for subjective judgements in allocating rewards and sanctions in the organization as against those allowing for set (presumably, objective) standards. Personalism Vs Impersonalism referring to a disposition that places primary emphasis on the person or on particular individuals as against that which emphasises material means for achieving performance. The universalist (or convergence) framework holds that work orientations are not particularly affected by culture. Situational based frameworks or the divergence thesis posits that culture not only influences the work orientations of managers and supervisors but also organizational employees.

\section{African managerial behaviour is divergent from other cultures}

All organizations are in part a function of cultural norms and behaviors. Triandis, Botempo and Bond (1986) have argued that culture is a 'fuzzy, difficult to define construct'. 'Culture is rather like a black hole: the closer you get to it the less light is thrown upon the topic and the less chance you have of surviving the experience' (Grint, 1995:71). Sociologists, however, visualize cultures as ways of life shared by members. Not only do they include beliefs and values but also language, symbols and material artifacts. With regard to organizations the conception of culture by Hofstede and Bond has been much widely utilized. Hofstede and Bond (1988) define culture as the 'collective programming of the mind that distinguishes the members of one category of people from another'. They refer to culture as the software of the mind. The language of programming and software is just an analogy. Individuals are not computers, machines or robots. People behave in certain ways not only because they choose to act that way but also they do so in different situations. In other words, although cultures may 'act' to control behaviour, they are creations (although by no means designations) of human beings. Cultures are important to managerial behaviour because they provide the context in which people make choices about how they will act but also who they want to be. In other words, issues of culture are bound up with those of identity. Hofstede (1995) talks in terms of culture having symbolic value to people. People develop part of their identity from it, it is part of the 'Who am I'. People may even fight if they feel that their cultural identity is threatened. Cultural differences 'are felt by people to be a reality and therefore they are a reality' (Hofstede, 1995:141). Most individuals are concerned with their own identity. An identity may be said to be a classification to which a person belongs and the qualities that he or she believes rightly or wrongly to be ordinary for a member of that category. For many people identities are rarely negotiable. Managers are not immune to these things. "Culture is a sufficiently powerful force to ensure that managerial values will continue to remain different for businesses from different countries despite the impact of western style industrialization' (Ralston \& Gustafson, 1993:249). According to Nancy Adler (1991:40) 'Each of us has a set of attitudes and beliefs - a set of filters through which we see management situations'. It is these views that form the background to research claiming that African culture conditions the nature of managerial work.

Managerial Behaviour in Africa: some authors say that the available evidence points to the fact that African managers are very personal in the way they operate. One important study linking African managers to personalism was by John Montgommery (1987). There have been various attempts to replicate Montgommery's very influential study in Africa. Montgommery utilized a Critical Incidences Procedure (CIP) to gather data from managers in Angola, Botswana, Mozambique, Swaziland, Zambia and Zimbabwe. The CIP as a method involved asking high-level public servants and private sector managers to describe events in their daily working lives in a period of 7 to 10 days. The descriptions given by managers in the sample were probed by Montgommery using three tests: analyzing the functions of managers; analyzing their goals and how they went about achieving them and analyzing the bureaucratic politics they engaged in. He found that personalism was a dominant orientation in the work of these managers. Functional analysis revealed that most of the managers saw themselves as acting on their own behalf preferring to leave others as organizational spokespeople. Goal analysis also revealed that personal interests rather than those of the client or the public inspired the goals pursued by these managers. Every organization processes power and is therefore inescapably political. Montgommery's analysis of bureaucratic politics showed that for most managers politics did not centre on policy but on the convenience of users. Montgommery's findings were supported by earlier studies by Hyden (1983) who found that many African managers would regard the impersonalism of western managers as scandalous. Blunt (1983) also came to the same conclusion. Related to personalism, many African managers display an authoritarian work orientation. They see themselves as personally responsible for all the decisions made in areas they oversee (Moris, 1977). Consequently, they become too concerned with domain or territoriality. Montgommery (1987) found that the bulk of the managers in his SADCC sample had a high sense of territoriality. They simply did not tolerate what they perceived as interference from other sections of the organization. Functional and bureaucratic politics analysis done by Montgommery revealed that managers were hemmed in departmental issues at the expense of those of the wider organization. As a result they lost sight of how their departmental goals fitted in with those of the larger organization. Other studies have found that rules are treated as very important but not in terms of their flexible use to advance organization goals but to preserve personal power within one's domain. Rules and 
regulations are worked to reward those subordinates who contribute to a given manager's authority. Thus Kiggundu (1988) claimed that African organizations show great power distances between managers and their subordinates. In particular, managers exercise close control over their juniors and they do not tolerate those that disagree with them. They do not take kindly to juniors who make decisions without consulting them. All these are features of very centralized and tall organizations that African organizations are. A consequence of all this is that subordinates in African organizations do not experience work as a central life interest. Many display an instrumental attitude towards work whereby it is just a means to a salary at the end of every month (Blunt \& Jones, 1992). In other words, favoritism is an important work orientation in this context because it fosters loyalty to individual managers.

The issue of favoritism as a work orientation needs further elaboration. Leonard (1993) found that although favoritism was widespread among managers there was the expectation that a manager should have personal and professional integrity and therefore abstain from favoritism. In Leonard's words professionals and managers may not practice what they preach, but they do believe what they preach. 'Their views on integrity have something of the same status as American views on marital fidelity in presidential politics. Even those who do not practice the ethical code themselves believe that those who break it do not deserve to hold leadership positions' (Leonard, 1993:48). Leonard found that professional integrity was a precondition for effectiveness in African organizations.

More recent studies of managerial behaviour (many still trying to replicate Montgommery's study) in the African context have more or less confirmed these findings. Vengroff, Belhaj \& Ndiaye (1991) tried to replicate Montgommery's SADC study using data from francophone Africa. More specifically, they wanted to investigate the skills that are displayed by managers in the Central African Republic (CAR), Senegal, Chad and Zaire. Their conclusions were very similar to those of Montgommery (1987). One difference they found was that in the francophone sample managers placed greater emphasis on monitoring workers and their work than in the SADC sample. Supervision was also seen as of less importance in the francophone sample than in the SADC sample. Lubatkin, Vengroff, Ndiaye \& Veiga (1999) also confirmed similarities between managerial work behaviour in the SADC and francophone countries. Lubatkin et al. (1999) found that organizations are perceived to function best when the decisions of super-ordinates are carried out without being questioned. Paternalism was found to be a standard organizational practice. The amount of effort and performance was not normally regarded as essential for promotion and managers overemphasized routine skills in gauging the performance of subordinates. Like their SADC counterparts Senegalese managers regarded external relations as extremely important. Lubatkin et al. (1999) found that although managers described their behaviour in the above terms they distinguished between what happens and what ought to happen. Managers' views of what ought to happen are not very different from those of Western managers. 'In summary, Senegalese managers appear to hold similar normative perceptions of what is important, regardless of their employment situation. This pervasive commonality suggests the presence of some national values of the workplace that supersedes any employment related influences' (Lubatkin et al., 1999:265).

Another widely noted element in the African context has to do with politics and the concentration of power. Montgommery's (1987) SADC study found that managers were, in the African context, too open to political ideologies. Leonard (1993) agrees by arguing that political connections in Africa are essential to managerial effectiveness. To be sure, Public Administration in African countries is very centralized. To be fair this is a feature carried over from the various colonial administrations (Rimmer, 1993). The pattern of centralized authority has spilled over into private enterprise. Managers are 'mainly intent on controlling and micro-managing the individuals and organizations below them' (Dia, 1994:169). Delegation of authority is rare and the exercise of individual discretion on the part of the subordinate rarely encouraged. This creates numerous problems of efficiency and effectiveness. Some of the problems pertain to the fact that managerial jobs involve high degrees of uncertainty. Managerial tasks are uncertain for several reasons. First, not all the information is available to managers to enable them to arrive at rational decisions. Second, it is impossible for managers to always take into account all operating procedures necessary in making decisions and lastly, it is difficult for managers to specify all contingencies before hand. Therefore for managers to operate effectively in organizational circumstances they need personal discretion. Concentration of power simply negates this. It turns African managers into inflexible operators who rely on personal whim to get by. This renders managers ineffective.

In my view there are several methodological problems in the studies reviewed above. The CIP associated with Montgommery is a set of procedures for identifying behaviour in a systematic manner that contributes to the success or failure of individuals or organizations in a demarcated situation. Despite the warning from Agle and Caldwell (1999) that 'most people do not know and are unable to articulate their value priorities' the CIP relies on self reported data to uncover managerial values. One widely noted difficult with self-reports involves recall. The critical incidences or relations managers say they are involved may not resemble the relations in which they are actually involved. Managers may say that they are involved in certain incidences just because it is prestigious to do so. Similarly, self-reports on disapproved behaviour such as that involving disciplinary action or punishment may focus on trivial or minor incidents. This brings to mind the old age problem of the relationship between attitudes and behaviour. The CIP also faces the potential problem that managers' description of incidences might reflect experiences within organizations rather than single clearly recalled incidences. The CIP may be too narrow to capture the complexity of managerial behaviour. Lastly, the CIP is poorly suited for cross-national comparisons because the unit of analysis is the specific incident not the manager. In Montgommery's (1987) study most of the people interviewed came from Lesotho (a quarter of the sample) and Zimbabwe (a third of 
the sample). The other five southern African countries included only provided few respondents. Again this raises questions of comparability. When Montgommery compared managers from Lesotho and Zimbabwe to managers from the other countries he did not control for the large differences in absolute base numbers of managers from which the comparisons were made. When one base figure is small, even a slight change will exaggerate its rate change and likewise a sizeable increase in the large base will appear minor in the rate change. Thus the peculiar experiences of a single manager from countries other than Lesotho and Zimbabwe could distort the findings.

These problems with the CIP method motivated Lubatkin and others to revert back to survey procedure. Ultimately, they wanted more randomized data that was amenable to statistical analysis. They extended Montgommery's (1987) work by converting each skill into a corresponding closed ended structured item. They developed sets of Likert type items in which managers were asked to rate the importance of each skill for her/his job and to rate the frequency with which they used the skills. Examples of these skills included 'commanding respect - is a person who is followed and listened to by subordinates' and 'community relations develops good working relationships with local community'. The Likert types items used by Lubatkin and others appear a bit superficial as measures of skills in that they do not provide a comprehensive explanation of what managerial skills actually are. Although, Lubatkin et al. (1999) criticized Montgommery they followed his use of the national states, as a unit of analysis forgetting that within African national states exist myriads of cultures and subcultures. Ethnic group cultures may be more relevant object of study than national cultures. Thus their comparison of Senegalese data to Montgommery's data is problematic.

\section{Influence of African culture and managerial orientations}

Most social scientists believe that the work orientations displayed by many managers in Africa can be attributed to the social cultural and political context within which government and business must be conducted in the continent (Moris, 1977; Hyden, 1983). Certainly, the emerging consensus among lay people and intellectuals alike is that many of the differences between African and non-African work behaviors may be due to fundamental dissimilarities in the value priorities of societies in which organizations are embedded (Leonard, 1993). Nzelibe (1986:11) summarized the argument nicely by stating 'Whereas western management thought advocates Euro-centrism, individualism and modernity, African management thought emphasizes ethnocentrism, traditionalism, communalism and cooperative teamwork'.

One relevant trait widely cited as typical of African cultures is the upholding of group rights. 'Community dominates all aspects of African thought. Dances are communal and worship is communal. Property was held in common before the colonial era and there are attempts today to reinstate that practice. This in-built bias towards community means that individualism is always seen as deviance'(Mutiso, 1974; quoted in Adler, 1991:153). Similarly, Shelton (1974) has confirmed widespread adherence to community in African cultures. 'The [African] value most clearly approved. ... is traditional communal responsibility revealed partly in the condemnation of self seeking individualism' (quoted in Adler, 1991:153). According to Grzeda and Assogbavi (1999) the prototype African business organization often takes on the community attributes; that is, it is built on close interpersonal relationships and group interactions and on the feelings of security and harmony that the group provides. Grzeda and Assogbavi (1999) also insist that individuals get their rewards from this submission and close association with the group. They are life long members and the group makes sure that they are not denied livelihoods. Additionally, African culture recognizes respect for elders, preservation of customs and toleration of waste in order to preserve harmony. Many managers in Africa are members of these cultures and are not immune to pressures to defend and/or promote group interests. These interests are 'characteristically those of widely extended families or clans, the units to which primordial loyalty was owed; and sometimes they coalesced for tactical purposes into tribal or ethnic groupings' (Rimmer, 1993:6). As Dia (1994) argued, African culture in general tends to be paternalistic and hierarchical, little prone to individualism tends to be egalitarian within the same age group but hierarchical in group-to-group relations with marked subordination of individual members. Within each group individuals have legal status and the capacity to perform specific acts, but a person wishing to go beyond his/her circle can do so only with the permission of authority figures. Grzeda and Assogbavi (1999:417) agree by stating "indeed African cultures are most accurately described as high power distance, since authority is assigned on the basis of age and experience, and is reinforced by a political system that centralizes power". This, as many observers have noted, runs counter to value assertiveness, individual freedom and responsibility. According to some it stifles initiative and creativity and encourages authoritarianism, personalism and favouratist orientations. Leonard (1987) believes that African managers are peculiar 'in the extent of their patronage obligations to poorer peoples and the strength of the moral pressures, which, they feel to fulfill them. For these reasons and for selfish ones that are far more universal, state organizations in Africa are used to pursue informal personal goals of managers rather than the collective ones that are formally proclaimed' (Leonard, 1987:901). In line with this managers are inclined towards favoritism and personalism. Corruption has its origins in this. Although no one can say corruption is unique to Africa, African managers seem to be distinguished by their lack of brakes in using offices for personal gain.

African culture promotes the principle of reciprocity. This principle as it applies to organizational behaviour has found expression in Southern Africa in the concept of ubuntu. The concept appeals to human dignity. It is an outlook of tolerance and kindness. It comes from the phrase Umuntu ngu muntu nga bantu meaning a person is a person because of (or through) other people (Economist, The, 1995; Saule, 1998). Ubuntu emphasizes the principle of helping others as away of helping oneself, collective activity and well being rather than individualism, unification rather than division, respect for elders and sharing (Saule, 1998). Some 
management practitioners have argued that the concept of ubuntu can be used as away of infusing modern management techniques with traditional African thought and culture to promote organizational performance and efficiency (Mbigi \& Maree, 1996). Although Mbigi and Maree perceive the concept of ubuntu as positive for management it still remains fuzzy. They provide very little explanation of how it could be injected into an organization. Less still do they show how it can co-exist with the spirit of individualism and competition that seem to drive modern organizations.

\section{African managerial behaviour is convergent with that in other cultures}

Not everyone agrees that African managerial behaviour is diverging from that which is found elsewhere. The major argument against those that argue for divergence of managerial behaviour based on cultural differences is the statement that what they are looking at is not unique to African managers. Thus, for instance, Montgommery's claim that African managers work better in private rather than in public organizations is not surprising for it applies to managers in many cultures. Comparing private and public management was something of a cottage industry in the 1970s and 1980s. Beginning with the seminal work of Parker and Subramanium (1964) through the work of Rainey et al. (1976, 1994) and Murray (1976) theorists have been arguing that private organizations are more efficient and effective, not because of culture but because of greater exposure to the market, relative autonomy from the state (i.e. politics and legal considerations) and their unique criteria for evaluating performance standards. Their effectiveness has also been attributed to the greater material incentives that private organizations offer relative to other organizations. Another example pertains to the argument that African managers are more personalistic, territorial and conservative than western managers. A casual perusal through such classics of organizational behaviour as Rosabeth Kanter's (1977) Men and Women of the Corporation and Eugene Jennings' (1971) The Mobile Manager reveal these to be widespread behaviours among managers in the West. Kanter (1977) in particular showed that female managers and male managers in token and powerless positions exhibited personalism, territoriality, and a lack of innovation in so far they lacked opportunities, numerical representation and more importantly, power at work. Many token managers were prone to these behaviours. In other words personalism, territoriality and conservatism should not be automatically associated with African culture as such but with the social structure and especially an individual manager's relation to the structure of opportunities and constraints in a given organizational context. It is also usually said that African managers are very patrimonial (Hyden, 1983) and tend towards corruption as they try to reward tribesmen and friends. Kanter (1977) found that in INDSCO- an organization in the United States there was a process of homo-social reproduction i.e. the use of gender, race, social background and family status to determine who will advance up the organizational hierarchy. In particular she found that only those that were similar to the decision makers in the organization (i.e. those with homo-social characteristics) stood a chance of promotion. In particular white, college educated, Northern European males had the best chances of advancing up the organizational ladder.

Thomas and Schonken (1998a \& 1998b) have questioned the supposed divergencies between managerial behaviour in Africa and elsewhere using research that was conducted in South Africa. Thomas and Schonken (1998a:54) argue that, in calling for a culture specific management style, African management commentators may be 'guilty of invoking questions of culture without a full understanding of the difficulties involved'. According to them methodological and other obstacles abound in research focusing on culture. They argue that no theorist has exactly spelled out a culture specific management largely because the investigation of culture is fraught with difficulties. Culture is difficult to quantify and compare and this places limits to how far researchers can correlate culture and managerial behaviour. Secondly, the concept of culture itself is a complex one. Thomas and Schonken (1998a:55) follow Geertz (1975) who warned against reifying culture by conceiving of it as a 'self contained super organic reality with forces and purposes of its own. Nor culture should be reduced'. I believe Thomas and Schonken (1998a) are saying that there is a danger of falling into ethnocentrism when cultural explanations are utilized with little or no caution. I would also venture that research in this area must be complicated by causal complexities. It is hard to believe that there is a simple vector of cause and effect governing the culturemanagerial behaviour dynamic. Time lags, non-linearities and feedbacks must enter the picture where the relationship between culture and managerial behaviour is concerned.

Thomas and Schonken (1998b) specifically tested the argument that there are four cultural worlds of management. The first world of management is the western one where the defining cultural traits are competition and individualization related to western empiricism. The individualist manager is motivated by profit and therefore places a high premium on personal initiative. Such a manager strives for self-reliance and independence. It is strongly rooted in Britain but is well entrenched in North America. Organizations and managers, as they are known today, are not home grown institutions in Africa. They were transferred from Europe - specifically in the entrepreneurial and rationalizing culture of Europe (Weber, 1948). The highly differentiated organizations of the modern type have continued to be a means of administration in which the planning and integration of activity is carried out on the basis of impersonal and standardized criteria. Organizations involve cooperation among many individuals, each of whom performs a specialized function. The hierarchy of authority within organizations ensures that tasks are distributed as official duties supervised by higher offices. Rules and regulations specify relations between people and ensure that tasks are carried out. Ideally positions are filled on merit. Impersonality is highly valued. For instance, authority belongs to the position and not to the occupant. Those who work in organizations must treat clients as 'cases' without hatred or passion and hence without affection or enthusiasm (Weber, 1948); and jobs are not given on the basis of emotional considerations such as family ties or friendship. This type of organizational system has proved to be most 
effective for several reasons: it encourages decisions taken according to general criteria rather than personal whim or caprice; meritocracy assures competence; and impersonality reduces corruption. Ideally for the system to function properly managerial work orientations must conform to impersonal and standardized criteria. The second world of management draws on the western cultural heritage but is labeled Northern rationalism. It is strongly rooted in France but also manifested in other European countries such as Scotland and Prussia, Northern Italy, Scandinavia and even the North Eastern seaboard of the United States. The northern rationalist manager is less competitive and individualist than the western manager.

The third cultural world of management is said to be Eastern Idealism. The essence of this is the Japanese way that emphasizes holistic practices, although more negatively it tends towards totalitarianism. The major cultural element in this managerial world is cooperation. The Chinese way is another example. Selmer and Kang (1994) have argued that for Hong Kong the influence of Chinese culture on management is very strong. Chinese culture, which is based on Confucius' teaching, has endured for more than two millennia. It emphasizes society, the group and hierarchical relationships within society (Ralston \& Holt, 1997). Similarly Taoism and Bhuddism (the other two important religions in China) also emphasize these values (Ralston \& Holt, 1997). In their study linking management to culture in Hong Kong, Selmer and Kang say that there is a definite and identifiable Chinese managerial system in which firms display a conservative security approach to internal management. It is a managerial system in which superordinates are authoritarian while subordinates are passive and submissive in organizational hierarchies. Social distance in Chinese organizations does recapitulate power differences. Despite this, super-ordinates do show a lot of benevolence towards their charges in Chinese organizations. These features ultimately reflect Chinese Confucian culture in which the family is at the centre of events. A manager is like a family head exercising paternalistic but considerate authority. Selmer and Kang (1994) further point to other features of Chinese management. These include the centralization of decision making power, keeping information secret and under tight control, and lack of recognition for individual effort. These facets of organizational life are quite different from organizations, as they are known in Europe (world 1) and Africa (world 4). Lastly is the managerial world of Southern humanism. The essence of this world is communalism and, more negatively, corruption and nepotism. The communal manager is nonrationalist, and is motivated by respect hence is prepared to give and share what is available. It is strongly rooted in African soils. As a matter of fact African culture is depicted as strongly democratic and egalitarian and participative decision making is seen as part and parcel of African tradition.

The objective of Thomas and Schonken's (1998a \& b) research was to see the extent to which Lessem's worlds of management would be used to address culture related issues in South African work hierarchies. Fortunately South Africa is a microcosm of many cultures. There are managers that have cultural roots in many of Lessems world of management. In particular there are managers with European origins and those that are from (and therefore steeped) in African culture. Thomas and Schonken (1998b) hypothesized that black South African managers and supervisors (since they are closer to African culture) would subscribe more to model 4 (Communal management) rather than to model 1 (Western management), model 2 (Northern rationalism management) and model 3 (Eastern management). It was also hypothesized that non black managers in South African management (i.e. those of European origin) would subscribe heavily to world 1 than to world 2, 3 and 4 of management respectively. Thomas and Schonken's (1998b) results showed that there was no support for the proposition that South African managers would subscribe more heavily to world 1 than to world 2, 3 and 4 of management respectively. As a matter of fact, $50 \%$ of white managers and supervisors, as did $43 \%$ of their black counterparts, subscribed mainly to world 4 of communal management. Similarly, $48 \%$ of white middle managers, as opposed to $58 \%$ of black managers and supervisors, subscribed to world 3 of eastern management. Only $8 \%$ of white managers and supervisors subscribed to world 2 of northern rational management and 5\% mostly subscribed to world 1 of individualism management. Contrary to expectations of the cultural worlds of management most white and black managers subscribe to world 3 of eastern management closely followed by world 4 of communal management. The proposition that African culture affects managerial values seems to have had little support in this research. Thomas and Schonken (1998b) also found very little support for Lessem's argument that African culture is strongly egalitarian and democratic since there was little correlation between measures of small power distance and subscription to world 4 of communal management. Assuming that white and black managers in South Africa are harbingers of different cultural values, Lessem's four worlds of management framework is not very helpful in identifying the influence of culture on management. As a matter of fact, there was more support for convergence of management than divergence of management based on cultural differences as they suggest that the influence of American and British systems of management shaped the organizational cultures under study and influenced the cultural values expressed by the managers included in their study.

Thomas and Schonken used survey procedures akin to the ones employed by Hofstede. Unfortunately those who follow Hofstede have huge problems with defining and operationalizing the concept of culture. Like Hoftede (1995) they perceive national culture as the sum total of individual personality traits in a given country. They operationalize it in the context of surveys of employees representing different countries (races in the case of Thomas and Schonken). The problem is with reducing culture to aggregated personality traits based on given dimensions (i.e. power-distance, uncertainty avoidance, individualism-collectivism and masculinity-femininity). For example, 'higher masculine traits are considered to exist if respondents agreed with a series of statements like - big and fast are beautiful' (O'Reilly, 1996). This is too simplistic. A related problem already alluded to is that modern societies do not exist with one culture, they are multi-cultural. Many surveys of 
managerial values do not account for this fact. Although Thomas and Schonken realized that South Africa is a country with many cultures, they conflated culture with race. They could only identify blacks, whites, Indians and 'coloureds' despite the fact that within whites are Afrikaners and English and within blacks are Zulus, Tswanas, Vendas, Xhosas, etc. Their study did not account for these groups that many would argue represent different cultures. Thomas and Schonken's (1998b) use of convenient sampling is, as they recognize, a limit on the generalizability of the study. Cross-sectional surveys cannot account for the fact that values in particular and cultures in general change. This is problematic in the African context where countries are caught between their own traditions and the dominating values transmitted by globalization and its social agents (including modern, and especially multi-national, organizations). O'Reilly (1996) argues that values on their own are not enough to understand practices at work and in organizations. To understand practices and behaviour, researchers must take into account the social and economic structure of given societies. Few studies on the African culture-managerial behaviour dynamic bother to look at institutions and societies in which organizations are embedded. This criticism applies to Thomas and Schonken too. Thomas and Schonken's study may have difficulty distinguishing between communalism and collectivism. Using in-depth interviews Jackson (1999) found that although South African managers say they are group oriented, they do not like relinquishing control to groups. Many are not in favour of automatic harmony, absence of confrontation or subjugation to group interests, as is the case in south East Asia.

\section{Clarifying the connections}

In studies linking managerial behaviour to culture the concern is with understanding; whether culturally derived values contribute to organizational efficiency; how culturally derived values contribute to organizational effectiveness and how culture affects the design and functioning of organizations. The major issue in this context has been the extent to which managers in Africa diverge from or converge with managers in other parts of the world. Convergence is the belief that organizations have an internal logic that forces upon managers and employees significant commonality in values pertaining to economic activity and work related behaviour. Divergence on the other hand is the belief that national cultures (and not the internal logic of organizations) are the main determinant of values that relate to economic activity and behaviour at work. This issue is not an insignificant one because 'If people around the world are becoming similar, then understanding cross cultural differences will become less important. If people remain dissimilar, then understanding cross cultural differences in organizations will become increasingly important' (Adler, 1991:60). The implication of divergence is that for organizations that operate in more than one culture a way must be found to bypass cultural resistance to procedures that may negatively affect efficiency and effectiveness. Organizations in Africa (because they are not home grown institutions) are among those that will have to strive to find ways of using cultural differences to advantage rather than to ignore them to cause problems.
Clearly the research linking African culture to managerial behaviour looks at differences between managers in Africa and elsewhere. The observed differences in managerial behaviour are then attributed to African culture. Researchers should however, be careful with using culture as an explanation of behavior. If they are not, for one, such an explanation can easily degenerate into an excuse for why anything or nothing can be (or is) done. If care is not taken cultural explanations can also degenerate into ethnocentric ones whereby cultures are evaluated in terms of their superiority and inferiority instead of (more correctly) their differences. Secondly, cultures are dynamic, changing and sensitive and African cultures are no exception. It must be emphasized that there is not one but many African cultures. Certainly the cultures found in Senegal cannot be the same ones found in South Africa. Do all the African cultures have the same or similar influence on managerial behaviour? Thirdly, there are elements in African cultures that are important in meeting the challenges of change. Thus emphasis on the group comes with skills of achieving consensus in decision-making and management theorists tell us that this is important in rallying organizational actors behind goals. Emphasis on the group also encourages the principle of reciprocity that is necessary for 'team building' and the lessening of authoritarian orientations (Bryant, 1994).

A usual failing of research in the African culture-managerial behaviour dynamic that may help clarify the inconclusive results is the reluctance to specify the types of differences that exist between African managers and managers in other places. Are the observed differences those of trait, relation, degree or kind? What type of effects does culture exert on behaviour? Scott (1986) has pointed to four types of effects that may be exerted by culture on organizational behaviour:

(1) Differences of degree; i.e. the behaviours that managers exhibit are found in both African and non-African organizations but the degree to which they are manifested is different.

(2) Trait differences; i.e. there are elements of behaviour unique to African management but on the whole this type of management is like others.

(3) Relational differences; i.e. there are distinctive behaviours in African management that result from the interaction of certain variables, which are artifacts of African culture.

(4) Lastly, a difference of kind; i.e. African culture has led to distinctive type of administration that has resulted in distinctive managerial behaviours.

In my view the question of whether or not managers in Africa are diverging or converging with managers in other parts of the world cannot be effectively answered unless researchers specify the type of effects that culture may exert on managers and their organizations.

It is possible that both processes of divergence and convergence are occurring at the same time. Thus researchers cannot be oblivious to the fact that technology that, managers in Africa use, the overt structuring of 
organizations and other aspects of their macro situation seem to be similar to those that are found in other parts of the world. Yet, micro issues such as behaviour within organizations seem to diverge. In this respect, 'organizations worldwide are growing more similar, while the behaviour of people within organizations is maintaining its cultural uniqueness' (Adler, 1991:57). It is only when researchers differentiate culture according to traits, relation, degree or kind that researchers can be able to see whether both divergence and convergence are taking place. The argument that values or more broadly culture explains the observed differences between managerial behaviour in Africa and elsewhere can be criticized for ignoring differences in resources (financial capital such as money and property) and human capital (skills, education and knowledge) between managers in Africa and elsewhere. For instance Mathews' (2000) research in Zambia revealed that the poor educational system and high inflation, along with the AIDS epidemic, resulted in unmet demand for skilled labour and consequently, in the use of an authoritarian management style. Managers felt that they needed to use an authoritarian style because some employees lack the technical skills to make good decisions (Mathews, 2000:13). Moreover, studies linking African culture to managerial behaviour ignore the structural context (i.e. power, numerical representation of managers of different ethnic groups, sex, opportunity structure, etc,) in which managerial behaviour occur. These might be moderating the supposed influence of African culture. No study that ignores these variables can be complete in its investigation of how culture affects behaviour.

A second possible explanation for the equivocal evidence regarding the relationship between African culture and managerial behaviour is the failure of most researchers to specify the link between culture and behaviour. It is possible that, as many social anthropologists for example, claim, dividing culture from behaviour is a futile exercise. To talk of the influence of culture on behaviour or the effects of cognition on behaviour is 'attempting to link two things that should never have been divided in the first place... the theoretical attachment of cognition to behaviour seems ... like a bandage on self inflicted wound' (Chapman, 1996/7:38). If this is the case it is small wonder that there are so many contradictory findings on how culture influences managerial behaviour.

Assuming that culture and behaviour can be analytically separated I believe that many organizational theorists utilize the concept of culture loosely without specifying how it should be analyzed and its practical implications. Culture is defined sociologically as the values, beliefs, norms and practices and material objects that together form a peoples' way of life. As sociologists insist, culture usually manifests itself in tangible and intangible ways. It can also be perceived in various ways in any given organization. 'Values, norms, and practices reflect different levels of observability of an organization's culture, but the concepts are also fundamentally interrelated. Values are manifested in norms that, in turn, shape specific practices' (De Long \& Fahey, 2000). In the form of values culture manifests itself as understood preferences of what the organization should endeavor to accomplish and how it should do so. Values are often not easy to enunciate and even more complicated to transform. The impact of values on organizational behaviour and practice should, however, not be underestimated (De Long \& Fahey, 2000). If one strong value of a culture is that women are less important than men, then specific actions towards women will be expected. Organizations will be unlikely to promote women, to listen carefully to their contributions, and to even respect what they do. Values that inspire individuals to disregard the autonomy of women are more likely to de-motivate them in organizations.

Norms are expectations or rules of conduct that guide people's behaviour. Norms are generally derived from values, but unlike values, which involve general preferences, they are specific guidelines for behaviour. Therefore they are more observable and identifiable. Thus, they are also more open to change (De Long \& Fahey, 2000). For example, men and women dress 'appropriately' for work places, and show a certain respect towards superordinates and older people. If someone dresses inappropriately or addresses an older person in an unbecoming manner, then the social norms governing how individuals interact will not support the behaviors needed to create and sustain a smooth working place. Norms provide a script for personal behaviour and allow us to a certain extent to predict how others are going to behave. By so doing norms provide the order and stability necessary for organizations to exist and operate.

As De Long and Fahey (2000) insist practices are the most observable signs and expressions of a culture. Practices show the sets of repetitive behaviors, such as when people report to work, how people in an organization hold meetings or write reports. Practices include repeated types of interactions that involve certain roles and social rules. Practices can be changed to support organizational performance. For example, meetings may be changed so that differences of opinions are encouraged and respected. Organizational leaders may change practices so that conflicts are managed constructively, or suppressed.

To clarify inconclusive research on the African culture managerial behaviour dynamic there is a need to understand and specify links between cultures in general and behaviour. In my view;

1. Culture shapes assumptions about what is important, useful and relevant in organizations (De Long \& Fahey, 2000). I am thinking of assumptions on the importance of individualism rather than collectivism, asceticism rather than rationality, subordinate responsibility rather than subordinate rights, altruism rather than hedonism, work as a central life interest rather than family as a central life interest etc. It may be useful for researchers to see how culture structures these and related assumptions that predicate behaviour in organizations. The work of Hofstede and others have gone quite a long way in this regard but clearly is not enough.

2. Culture helps to define individual interests thereby mediating the relationship between the individual and the organization (De Long \& Fahey, 2000). I define interests as activities that people expect to attain within 
a given situation. These are really what are important to them as they strive to attain their needs. For example if one is interested in the well being of others $\mathrm{s}(\mathrm{he})$ may not mind an authoritarian leader that takes subordinate well being into account. S(he) may support a paternalistic leader. On the other hand an individual that is interested in her/his own well being may see authoritarianism as anathema. Interests may be seen as close to behaviour. An interest in material well being leads to wealth seeking behaviour and having an interest in power may lead to seeking positions with authority. If a researcher wants to know how culture relates to behaviour, she or he must know the activities in which people are likely to seek their goals. The researcher must know the interests of his/her subjects.

3. Culture creates the rules for social interaction that conditions how people will react to others within the organization. Every form of interaction occurs according to rules (norms) of what is appropriate form of communication according to gender, age, social status, kinship etc. there are restrictions on how free interaction should be between super-ordinates and subordinates, when and how it should take place. They are rules on who should share information and the approachability of seniors. Social rules and regulations may not apply to men and women equally. They certainly serve to give more power to certain groups than to others. Researchers will know more about how culture relates to behaviour if they investigate how social rules apply in organizations that are embedded in different cultures. These social rules (deriving from culture) define the context in which action or behaviour occurs

4. Culture shapes processes of power - how it is distributed and legitimated within organizations. Legitimate power is an interactional concept belonging to decision-making variables. It can only be defined in relation to the actions of individuals in group settings. Enduring power is a matter of commanding loyalties; it can only be secured with the cooperation of others and not through mere command, authoritarianism, rule mindedness and favouritism. For managers in organizations to have power they must be credible; i.e. power derives from performance as individuals are evaluated by relevant others in accordance with normative prescriptions. 'Being powerful rests on being included in calculated strategies and decisions, being included in strategies and decisions rests on other's evaluation of one's accountability, which in turn rests on one's willingness to obey group standards of behaviour, which includes the norm for exercising power' (Hamilton \& Biggard, 1985:12). Managers can only have power if they evaluate themselves and, more importantly, are evaluated by others as successful at having things done. This is where culture comes in for it helps provide standards by which relevant others in the organization evaluate or judge a manager. Researchers will know more about how culture relates to behaviour if they investigate how managers in different cultural settings go about securing legitimate power in organizations.
This study has not been reticent in questioning the robustness of the methods utilized in investigating the impact of African culture on managerial behaviour. To this end the critical incidences procedure (CIP) used by Montgommery and the surveys used by Lubatkin and associates and Thomas and Schonken (1998b) have been criticized. By definition research on the African culture - managerial behaviour dynamic is cross cultural research. Therefore any measurements of the concepts employed must address the issue of equivalence. A problem with Montgommery's (1987) study was that he could not assure functional equivalence of critical incidents involving managers in Lesotho, Botswana, Zambia, Zimbabwe and the other countries. This problem is not only limited to the CIP but extends to surveys. 'Meaning vary between cultures and this raises a particular problem in the use of surveys in cross national (or cross cultural research) where meaning equivalence is an important component of a questionnaire's validity' (Mays, 2001:214). As Mufune (1991) argued drawing samples of managers in different countries may mean different sample sizes and sample characteristics (age range, sex, educational and professional achievements, experiences, etc). This calls the equivalence of the two samples into question, as they may not be comparable. There is also the danger that surveys may value surface facts over genuine understanding. In my view to get out of this problem researchers on the African culture-managerial behaviour dynamic must have some understanding of the social context with which they are dealing with. They must be sensitive to indigenous factors in which organizations are embedded. Sensitivity to the context in which managerial behaviour is generated requires not only generalization but also, even more importantly, depth. Considerations of meaning are inescapable where culture is a variable. This means that in-depth qualitative or inductive methodologies are necessary in studies that link culture to managerial behaviour. This is not to say that studies such as those inspired by Hofstede are useless, but rather that they are inadequate and must be complimented by qualitative more in-depth look at the cultural meanings of the subjects of study. Secondly, use of the national state as a unit of analysis is in the African context misplaced. Within African national states myriads of cultures and sub-cultures exist. Ethnic group cultures may be more relevant object of study than national cultures, which at any rate are very new creations in many African states. In any case it could be difficult to study in depth the national state as a variable as it exists at a higher level of abstraction.

\section{References}

Adler, N. 1991. International dimensions of organizational behaviour. Belmont: Wadsworth.

Agle, B. \& Caldwell, C. 1999. 'Understanding research on values in business', Business and Society, 38(3):326-387.

Beugre, C. \& Offodile. O. 2001. 'Managing for organizational effectiveness in Sub-Saharan Africa: A 
culture fit model', International Journal of Human Resource Management, 12(4):535-550.

Blunt, P. 1983. Organizational theory and behaviour: An African perspective. London: Longman.

Blunt, P. \& Jones, M. 1992. Managing organizations in Africa. Berlin: Walter de Gruyter.

Bryant, C. 1994. 'Culture, management and institutional assessment'. In Serageldin, I. \& Taboroff, J. (Eds.). Culture and development in Africa. Washington, DC: World Bank.

Catley-Carlson, M. \& Outlaw, J. 1998. 'Poverty and population Issues: Clarifying the connections', Journal of International Affairs, 52(1):233-252

Chapman, M. 1996/7. 'Social anthropology, business studies and cultural issues', International Studies of Management and Organization, 26(4):3-30.

Delong, D. \& Fahey, L. 2000. 'Diagnosing cultural barriers to knowledge management', The Academy of Management Executive, 14(4):113-127.

Dia, M. 1994. 'Indigenous management practices: Lessons for Africa's management in the 1990s.' In Serageldin, I. \& Taboroff, J. (Eds.). Culture and development in Africa. Washington, DC: World Bank.

Economist, The, 334(7906):68, 1995. 'Ubuntu and other management tips'.

Geertz, C. 1975. The interpretation of cultures London: Hutchinson and Company Limited.

Grzeda, M. \& Assogbavi, T. 1999. 'Management development programmes in francophone sub-Saharan Africa', Management Learning, 30(4):413-429.

Grint, K. 1995. Management: A sociological introduction. London: Polity Press.

Hamilton, G \& Biggard, N. 1985. 'Why people obey: Theoretical observations on power and obedience in complex organizations', Sociological Perspectives, 28(1):128.

Hofstede, G. \& Bond, M. 1988. The Confucius connection: From cultural roots to economic growth', Organizational Dynamics, 16(4): 4-21.

Hofstede, G. 1995. 'Cultural relativity of organizational practices and theories'. In Drew, J. (Ed.). Readings in international enterprise. London: Routledge, pp. 140-158.

Hyden, G. 1983. No shortcuts to progress: African development management in perspective. Berkeley: University of California Press.

Jackson, T. 1999. 'Managing change in South Africa: Developing people and organizations', International Journal of Human Resource Management, 10(2): 306-326.
Jennings, E. 1971. The mobile manager. Ann Arbor: Bureau of Industrial Relations. Graduate School of Business Administration. University of Michigan.

Kanter, R. 1977. Men and women of the corporation. New York: Basic Books.

Kanter, R. 1991. 'Transcending business boundaries: 12,000 managers view change' Harvard Business Review, 69(63):151-164.

Kiggundu, M. 1988. 'Africa'. In Nath, R. (Ed.). Comparative management: A regional view. Cambridge Mass: Ballinger Publishing Company

Kiggundu, M. 1993. 'The Challenges of Management Development in Sub-Saharan Africa' In Blunt, P. M., Jones \& Richards, D. (Eds.). Managing Organizations in Africa: Readings, Cases and Exercises. Berlin: Walter de Gruyter.

Leonard, D. 1988. 'The secrets of African success', IDS Bulletin, 19(4):35-41.

Leonard, D. 1993. 'The secrets of African success', In Blunt, P. Jones, M. \& Richards, D. (Eds.). Managing organizations in Africa: Readings, cases and exercises. Berlin: Walter de Gruyter.)

Leonard, D. 1987. 'The political realities of African management', World Development, 15:899-910.

Lubatkin, M., Vengroff, R., Ndiaye, M. \& Veiga, J. 1999. 'Managerial work and management reform in Senegal: The influence of hierarchy and sector', American Review of Public Administration, 29 (3): 240-268.

Mathews, V. 2000. 'Management in a developing nation: And we thought American managers had it tough', Multinational Business Review 8(2): 1-6.

Mays, T. 2001. Social research. $3^{\text {rd }}$ Edition. Philadelphia: Open University Press.

Mbigi, L. \& Maree, J. 1996. Ubuntu: The spirit of African transformation management. Randburg. South Africa: Sigma Press.

Montgommery, J. 1987. 'Probing managerial behaviour: Image and reality in Southern Africa', World Development, 15(5): 911-929.

Moris, J. 1977. The transferability of western management concepts and programmes: An East African perspective. London: London International Institute of Educational Planning.

Mufune, P. 1991. 'Some problems in the use of network analysis for comparative enquiry', International Sociology, 6(1): 97-110.

Murray, M. 1975. 'Comparing public and private Management: An exploratory essay', Public Administration Review 35 (4): 364-371. 
Nzelibe, C. 1986. 'The evolution of African management thought', International Studies of Management and Organization, 16(2): 6-16.

O'Reilly, J. 1996. 'Theoretical considerations in cross national employment research', Sociological Research Online, 1(1).

Parker, R. \& Subramaniam, V. 1964. 'Public and private administration', International Review of Administrative Sciences, XXX (4): 1-11.

Rainey, H., Backoff, R. \& Levin, C. 1976. 'Comparing public and private organizations', Public Administration Review 36 (2): 233-244.

Ralston, D. \& Holt, D. 1997. 'The impact of national culture and economic ideology on managerial work values: A study of the United States, Russia, Japan and China', Journal of International Business Studies, 28(1):177-208.

Ralston, D. \& Gustafson, D. 1993. 'Differences in managerial values: A study of U.S., Hongkong and P.R.C. managers', International Business Studies, 24(2):249-276.

Rimmer, D. 1993. 'Thirty years of independent Africa'. In Blunt, P., Jones, M. \& Richards, D. (Eds.). Managing organizations in Africa: Readings, cases and exercises. Berlin: Walter de Gruyter.

Saule, N. 1998. 'Images of Ubuntu in the essays of SEK Mqhayi in Umteteli Wzabantu', South African Journal of African Languages, 18(1):10-19.

Scott, W. 1986. Organizations: Rational, natural and open systems. New Jersey: Prentice Hall.

Selmer, J. \& Kang, I. 1994. 'Managerial behaviour of expatriate versus local bosses', International Studies of Management and Organization 24 (3): 48-64.

Thomas, A. \& Schonken, J. 1998a. 'Culture-specific management and the African management movement - A critical review of the literature', South African Journal of Business Management, 29(2):53-67.

Thomas, A. \& Schonken, J. 1998b. 'Culture-specific management and the African management movement Verifying the premises', South African Journal of Business Management, 29(2):67-77.

Triandis, H., Botempo, R. \& Bond, M. 1986. 'The measurement of individualism and collectivism across cultures', Australian Journal of Psychology, 38(3):237-67.

Vengroff, R., Belhaj, M. \& Ndiaye, M. 1991. 'The nature of managerial work in the public sector: An African perspective', Public Administration and Development, 11: 95-110.

Weber, M. 1948. The theory of social and economic organization. New York: Free Press.
Wildavsky, A. 1994. 'How cultural theory can contribute to understanding and promoting democracy, science and development'. In Serageldin, I. \& Taboroff, J. (Eds.). Culture and development in Africa. Washington, DC: World Bank.

World Bank. 1981. Accelerated development in subSaharan Africa: An agenda for action. Washington, DC: World Bank. 